\title{
Scenario of Major Pulse Production in Tamil Nadu: A Growth Decomposition Approach
}

\author{
R. Sangeetha*, K.R. Ashok and P. Asha Priyanka
}

Centre for Agricultural and Rural Development Studies, Tamil Nadu Agricultural University, Coimbatore, Tamil Nadu, India

*Corresponding author: sangeethaeco2016@gmail.com (ORCID ID: 0000-0002-2198-3769)

Received: $23-12-2019$

Revised: $18-04-2020$

Accepted: 23-05-2020

\begin{abstract}
In the present study, an attempt has been made to analyze the trend in the production of the total pulses crop in Tamil Nadu for the period 1965-66 to 2016-17, i.e. past six decades in the state. The gross area under total pulses in Tamil Nadu was in the range of 3.97 to 7.85 lakh ha per year over these six decades. The average production of total pulses was in the range of 1.01 lakh tonnes to 3.37 lakh tonnes per annum. However, the yield of total pulses was increased over the year. The yield of total pulses was $256 \mathrm{~kg} / \mathrm{ha}$ during 1960's which increase to above $430 \mathrm{~kg} / \mathrm{ha}$ during 2016-17. The compound growth rate of yield over six decades was positive and significant in area and production except the period II are negative signs. Area under Black gram, Green gram, Red gram, Bengal gram and total pulses registered positive growth during 1965-66 to 1985-86. Increase production of Black gram, Green gram, Bengal gram and total pulses were contributed by their yields, whereas area and its interaction with yield have adversely affected the production. Decline in production of Horse gram was due to area effect and interaction effect. The decomposition analysis shows that increase in production of pulses during the period 20062016 was driven mainly by yield improvements. Since the supply of resources, especially land is limited in nature; productivity of pulses should be boosted up by the adoption of improved technologies like hybrid pulses cultivation and various techniques of production to meet the future increased demand.

\section{Highlights}

( To meet growing demand and to reduce the import of pulses, more such initiatives are needed, so that the country can attain self- sufficiency. Policy support should be promoted which will help to increase per capita availability of pulses, reducing import dependence and to some extent it will stabilize the pulse prices. This research will be helpful for policy makers to take decisions regarding performance of pulses in Tamil Nadu.
\end{abstract}

Keywords: Pulses, growth, area decomposition, Yield effect, interaction effect

Pulses is a major source of protein for a huge section of state particularly vegetarian population. India, with a share of 22 per cent, is the largest producer of pulses in the world. But the production of pulses has not been able to keep pace with their domestic demand, resulting in imports of 2-3 million tonnes of pulses per annum. For the two decades, post1991, pulses production is almost stagnated at around 14 million tonnes, leading to a significant decline in their per-capita availability, from $61 \mathrm{~g} /$ day in 1951 to $54.5 \mathrm{~g} /$ day in 2018 one-third less than the recommended intake of $65 \mathrm{~g} /$ day (ICMR, 2018). Further, the mismatch between demand and supply has made the pulses market more volatile. Closing the gap between demand and supply of pulses would require production to grow at least by 4 per cent per annum (Kumar, 1998; IIPR, 2011). During recent years people are recognizing the nutrient

How to cite this article: Sangeetha, R., Ashok, K.R. and Priyanka, P.A.
(2020). Scenario of major pulse production in Tamil Nadu: A growth
decomposition approach. Economic Affairs, 65(2): 301-307.
Source of Support: None; Conflict of Interest: None
(2020). Scenario of major pulse production in Tamil Nadu: A growth Source of Support: None; Conflict of Interest: None 
superiority and health benefits of pulses compared to other grains. There may be an increase in demand for pulses due to recent inclusion of pulses in food security bill coupled with increased awareness of people about inclusion of pulses in daily meals for healthy living and also pulses are ideal solution for climate change. So, there is a need to increase the pulse production with the increasing demand and to recognize them as climate change complaint crops to promote their cultivation and consumption which makes them state food and farming future. With this backdrop, the paper has examined to study the growth pattern of area, production, and yield of major pulses in the Tamil Nadu.

\section{MATERIALS AND METHODS}

The study uses secondary data pertaining to area, production and yield of pulses in India during the last six decades i.e. from 1965-66 to 2017-18 collected primarily from Agricultural Statistics at a Glance, Season and crop Report, Directorate of Economics and Statistics, Ministry of Agriculture, Tamil Nadu. The data was analyzed through percentages and averages to examine the change in area, production and yield of major pulse crops viz., Black gram, Green gram, Red gram, Bengal gram, Horse gram and total pulses.

\section{(i) Measurement of growth rate}

In the present study, Compound growth rates were calculated by exponentially fitting the time series data of area, production and yield of pulses and major pulse crops were calculated for three time periods viz., period-I (1965-66 to 1985-86), period-II (1986-87 to 2005-06), Period III (2006-07 to 2017-18) and overall period (1965-66 to 2017-18) at the state level against time using the following formula:

$$
Y_{t}=a b^{t} U_{t}
$$

Where,

$Y_{t}=$ Dependent variable for which growth rate was estimate in year $t$

$a=$ Intercept

$b=$ Regression coefficient

$t=$ Year which takes values $1,2, \ldots, n$.

$U_{t}=$ Disturbance term in year $\mathrm{t}$.
The equation (1) will be transformed into log-linear and written as:

$$
\log Y_{t}=\log a+t \log b+\log U_{t}
$$

Equation (2) will be estimated by using Ordinary Least Square (OLS) technique.

The compound growth rate (g) will be then estimated by the identity given in equation (3),

$$
g=(b-1) \times 100
$$

Where,

$g=$ Estimated compound growth rate per annum in percentage.

$b=$ Antilog of regression coefficient value.

\section{(ii) Decomposition of growth components}

Decomposition analysis was used to measure the relative contribution of area and yield towards the total production changes of major pulses.

This method is explained below:

$$
\begin{aligned}
& P_{0}=A_{0} \times Y_{0}, \text { and } \\
& P_{t}=A_{t} \times Y_{t}
\end{aligned}
$$

Where, $A_{0}$ and $A_{t}$ represent the area and $Y_{0}$ and $Y_{t}$ represent the yield in the base year and $n^{\text {th }}$ year, respectively.

$$
\begin{aligned}
& P_{t}-P_{0}=\Delta P, \\
& A_{t}-A_{0}=\Delta A \\
& Y_{t}-Y_{0}=\Delta Y
\end{aligned}
$$

Upon simplification of equation (1) and (2), it could be written as:

$$
P_{0}+\Delta P=\left(A_{0}+\Delta A\right)\left(Y_{0}+\Delta Y\right)
$$

Hence,

$$
P=\frac{A_{0} \Delta Y}{\Delta P} \times 100+\frac{Y_{0} \Delta A}{\Delta P} \times 100+\frac{\Delta Y \Delta A}{\Delta P} \times 100
$$

Production $=$ Yield effect + Area effect + Interaction effect

Thus, the total change in production can be decomposed into three components viz., yield effect, 
area effect and the interaction effect due to change in yield and area.

\section{RESULTS AND DISCUSSION}

\section{Status of Pulses Production in Tamil Nadu}

In 2017-18, Tamil Nadu produced 5.56 lakh tonne of pulses from an area of 8.24 lakh ha (Table 1). Over time, there has been an increase in pulses production mainly due to improvement in their yields; the average yield increased from $256 \mathrm{~kg} /$ ha in 1965-66 to $675 \mathrm{~kg} / \mathrm{ha}$ in 2017-18. Table 1 provides the disaggregated information on pulses by growing period, i.e. kharif (June-September) and rabi (October-Dec). The rabi pulses account for half of the total pulses area and contribute close to twothirds to the total production, and these proportions have not changed much over time, indicating no significant seasonal shift in pulses production. However, a faster increase has been observed in the average yield of rabi-pulses in the recent decade; it increased at an annual rate of 7.18 per cent during 2006-2016 as compared to 2.57 per cent in the previous decade of 1965-1985. The production of pulses, however, is concentrated in a few Districts in Tamil Nadu. The districts of Villupuram, Salem, Cuddalore, Thiruvarur, Vellore, Thiruvannamalai and Thanjavur account for more than 60 per cent of the total area as well as production of pulses (Table 2).

Table 1: Average Area of major Pulses in Tamil Nadu 1965-66 to 2017- 18

\begin{tabular}{lllll}
\hline & \multicolumn{4}{c}{ Average Area (‘000 ha) } \\
\cline { 2 - 5 } Crop & $\begin{array}{l}\text { Triennium } \\
\text { Ending }\end{array}$ & $\begin{array}{l}\text { Triennium } \\
\text { Ending }\end{array}$ & $\begin{array}{l}\text { Net } \\
\text { Change }\end{array}$ & $\begin{array}{l}\text { Percent } \\
\text { Change }\end{array}$ \\
\hline Black gram & $\mathbf{1 9 6 5 - 6 6}$ & $\mathbf{2 0 1 7 - 1 8}$ & & \\
Green gram & 42.78 & 417.10 & 372.78 & 840.99 \\
Red gram & 52.04 & 54.93 & 2.90 & 5.56 \\
Hose Gram & 200.79 & 58.91 & -141.89 & -70.66 \\
Bengal gram & 2.12 & 5.10 & 2.98 & 140.30 \\
Total Pulses & 397.79 & 832.24 & 434.45 & 109.22 \\
\hline
\end{tabular}

Villupuram has a higher share in the rabi-pulses. It alone accounts for one-third of the total production. On the other hand, Thanjavur and Thiruvarur have higher shares in kharif-pulses; together they contribute 17 per cent to the total production of kharif - pulses. Further probe shows that though pulses have a wider regional spread, there are niches for different pulses. Black gram production is concentrated in Villupuram (29\%), and Cuddalore (14\%); Green gram is concentrated in Thanjavur $(23 \%)$ and Salem (22\%); Red gram is concentrated in Vellore (33\%) and Horse gram is concentrated in Krishnagiri (23\%), and Bengal gram is strenuous more in Tiruppur (50\%). This indicates the need for crop - and region specific strategies for enhancing pulses production in Tamil Nadu.

\section{Change in area, production and yield}

The analysis of average area, production and yield indicated an increase in area and the increase in yield under all the pulse crops except Horse gram from TE ending 1965-66 to TE ending 2017-18 (Table 1). The total area under pulses increased from 397.79 thousand ha to 832.24 thousand ha $(109.22 \%)$ and the decline in the area was highest in the case of Horse gram $(70.66 \%)$ which contributes more to the reduction in the area under total pulses. The production of almost all the pulse crops increased over the study period due to the increase in yield despite of reduction in area under the crop, except in the case of Horse grams.

Table 2: Average Production of major Pulses in Tamil Nadu 1965-66 to 2017- 18

\begin{tabular}{lllll}
\hline & \multicolumn{4}{c}{ Average Production ( ‘000 tonnes) } \\
\cline { 2 - 5 } Crop & $\begin{array}{l}\text { Triennium } \\
\text { Ending }\end{array}$ & $\begin{array}{l}\text { Triennium } \\
\text { Ending }\end{array}$ & $\begin{array}{l}\text { Net } \\
\text { Change }\end{array}$ & $\begin{array}{l}\text { Percent } \\
\text { Change }\end{array}$ \\
\hline Black gram & $1965-66$ & $\mathbf{2 0 1 7 - 1 8}$ & & \\
Green gram & 10.28 & 283.97 & 269.87 & 1913.95 \\
Red gram & 23.63 & 59.53 & 79.25 & 770.89 \\
Hose Gram & 42.46 & 35.17 & -7.29 & -17.17 \\
Bengal gram & 1.09 & 3.80 & 2.71 & 248.35 \\
Total Pulses & 101.96 & 522.68 & 420.72 & 412.63 \\
\hline
\end{tabular}

Although, the yield of Horse grams is increased by $161.61 \%$, the decline in area under these crops $70.66 \%$. Shrinkage of area under Horse grams in Tamil Nadu is due to crop diversification towards commercial crops. With decline in area, impressive growth in production of total pulses was mainly contributed by growth in yield (Kannan and Sundaram, 2011). Green gram and Bengal gram recorded $770.89 \%$ and $248.35 \%$ increase in production with an increased yield of $85 \%$ and $44.36 \%$ respectively over the study period. Black 
gram production was increased vastly by $1913.95 \%$, which is largely attributed to the highest increase in yield 114.15 per cent among the pulse crops under study.

Table 3: Average Yield of major Pulses in Tamil Nadu 1965-66 to 2017- 18

\begin{tabular}{lllll}
\hline & \multicolumn{4}{c}{ Average Yield (kg/ ha) } \\
\cline { 2 - 5 } Crop & $\begin{array}{l}\text { Triennium } \\
\text { Ending }\end{array}$ & $\begin{array}{l}\text { Triennium } \\
\text { Ending }\end{array}$ & $\begin{array}{l}\text { Net } \\
\text { Change }\end{array}$ & $\begin{array}{l}\text { Percent } \\
\text { Change }\end{array}$ \\
\hline Black gram & 318 & 681 & 363 & 114.15 \\
Green gram & 240 & 444 & 204 & 85.00 \\
Red gram & 451 & 921 & 470 & 104.21 \\
Hose Gram & 211 & 552 & 341 & 161.61 \\
Bengal gram & 514 & 742 & 228 & 44.36 \\
Total Pulses & 256 & 626 & 370 & 144.53 \\
\hline
\end{tabular}

\section{Growth performance of area, production and} yield

Annual compound growth rates were calculated for the pulse crops during 1965-66 to 1985-86 (period-I), 1986-87 to 2005-06 (period-II), 2006-07 to 2016-17 (period III) and 1965-66 to 2017-18 (overall period) and the results are presented in Table 4 . Black gram registered significant increase in area, production and yield during period-I (1965-66 to 1985-86) with an annual compound growth rate (CAGR) of $8.28 \%, 9.14 \%$ and $0.80 \%$ respectively. Production of black gram reduced significantly $(1.96 \%)$ during period-II even though there is a significant increase in yield $(0.94 \%)$ due to high and significant positive growth in area $(2.03 \%)$, and also recorded significant increase in production with a growth rate of $14.16 \%$ per annum during the period III (2006-07 to 2016-17). The major reasons for productivity improvement were use of high yielding varieties and increased utilization of input for pulse cultivation (Hile et al. 2013).

With the exception of Horse gram, the area and production of most of the pulse crops in Tamil Nadu showed positive growth rate in the time period

Table 4. Compound Growth Rate for Major Pulses in Tamil Nadu (1965-2016)

\begin{tabular}{|c|c|c|c|c|}
\hline & Period I (1965-1985 ) & Period II (1986-2005) & Period III (2006-2016) & Overall Period (1965-2016) \\
\hline \multicolumn{5}{|l|}{ Black gram } \\
\hline Area & $8.28^{*}(7.761)$ & $2.03^{\mathrm{NS}}(1.002)$ & $4.69^{* *}(2.854)$ & $3.05^{*}(7.536)$ \\
\hline Production & $9.14^{*}(7.037)$ & $-1.96^{* *}(-2.436)$ & $14.16^{*}(3.603)$ & $4.42^{*}(10.529)$ \\
\hline Yield & $0.80(1.364)$ & $-0.94^{* *}(-2.015)$ & $5.15(1.543)$ & $1.30^{*}(6.445)$ \\
\hline \multicolumn{5}{|l|}{ Green gram } \\
\hline Area & $3.00^{*}(3.024)$ & $4.05^{* *}(2.850)$ & $4.21^{* *}(2.354)$ & $2.19^{*}(7.108)$ \\
\hline Production & $5.97^{*}(3.630)$ & $1.61^{* * *}(1.821)$ & $9.20^{\mathrm{NS}}(1.685)$ & $3.38^{*}(8.693)$ \\
\hline Yield & $1.77^{* *}(2.528)$ & $-0.22^{\text {NS }}(-0.491)$ & $2.11^{\mathrm{NS}}(0.459)$ & $1.22^{*}(5.153)$ \\
\hline \multicolumn{5}{|l|}{ Red gram } \\
\hline Area & $2.25^{*}(2.99)$ & $-5.21^{*}(-8.150)$ & $10.22^{*}(6.051)$ & $-1.06^{* *}(-3.177)$ \\
\hline Production & $2.25^{*}(5.541)$ & $-5.68^{*}(-7.140)$ & $14.04^{*}(4.105)$ & $0.02^{\mathrm{NS}}(0.053)$ \\
\hline Yield & $2.25^{*}(5.360)$ & $-0.50^{\mathrm{NS}}(-0.741)$ & $2.71^{\mathrm{NS}}(0.760)$ & $0.84^{*}(4.177)$ \\
\hline \multicolumn{5}{|l|}{ Bengal gram } \\
\hline Area & $7.32^{*}(4.478)$ & $-0.81^{\text {NS }}(-0.944)$ & $-1.49^{\text {NS }}(-0.886)$ & $0.67^{* *}(1.754)$ \\
\hline Production & $8.35^{*}(5.384)$ & $-0.90^{\text {NS }}(-0.967)$ & $-1.62^{\text {NS }}(-0.962)$ & $1.10^{*}(2.760)$ \\
\hline Yield & $0.92^{* *}(2.333)$ & $0.22^{\mathrm{NS}}(1.074)$ & $0.01^{\mathrm{NS}}(0.037)$ & $0.44^{*}(5.625)$ \\
\hline \multicolumn{5}{|l|}{ Horse gram } \\
\hline Area & $-2.16^{*}(-6.529)$ & $-3.51^{*}(-6.045)$ & $3.41^{\mathrm{NS}}(1.234)$ & $-3.13^{*}(-17.695)$ \\
\hline Production & $1.11^{\mathrm{NS}}(1.211)$ & $-4.35^{*}(-3.705)$ & $3.43^{\mathrm{NS}}(0.689)$ & $-1.26^{*}(-3.650)$ \\
\hline Yield & $3.11^{*}(3.959)$ & $-1.22^{* * *}(-1.855)$ & $-1.18^{\mathrm{NS}}(-0.489)$ & $2.01^{*}(8.755)$ \\
\hline \multicolumn{5}{|l|}{ Total Pulses } \\
\hline Area & $2.82^{\mathrm{NS}}(1.596)$ & $-1.37^{*}(-3.258)$ & $5.16^{*}(3.823)$ & $1.07^{*}(3.377)$ \\
\hline Production & $4.21^{*}(6.283)$ & $-2.30^{*}(-3.687)$ & $12.71^{*}(3.371)$ & $2.00^{*}(6.673)$ \\
\hline Yield & $2.57^{*}(7.624)$ & $-0.94^{* *}(-2.865)$ & $7.18^{* *}(2.644)$ & $1.31^{*}(7.462)$ \\
\hline
\end{tabular}

Note: * Significant at 1\% level of significance, ** Significant at $5 \%$ level of significance,

*** Significant at $10 \%$ level of significance NS - Non Significiant

Source: Computed from DES, Tamil Nadu 
I (1965-1985). Even though the area shows the negative growth, the production and productivity was positive and significant for all the crops except for Horse gram. This may be because of the introduction of new varieties, technologies and scheme (NFSM) and a few hybrids in select pulse crops such as Black gram, Green gram and Red gram.

The area and production of most of the pulse crops in Tamil Nadu showed positive growth rate in the time period III (2006-07 to 2017-18). Even though the area and production shows the positive growth, the productivity was positive and significant for all the crops except for bengal gram. Even though there is an increase in yield with the use of improved/ hybrid seeds, there is not much increase in production as farmers shift to other, more remunerative crops (Basavaraj and Rao, 2012). Significant positive growth in production $(2.76 \%$ CAGR) was observed in Bengal gram during overall period due to relatively higher increase in yield (5.62\% CAGR) and less decline in area $(0.91 \%$ and $0.18 \%$ CAGR).

Area under red gram increased significantly during period-I with an annual growth rate of $2.25 \%$ but reduced significantly during Period II and overall study period with negative growth rate of 5.21 and 1.06 per cent per annum. Although there was an increase in the yield of Red gram, higher decline in area resulted in reduction of total production by $7.14 \%$, during the second periods. All the pulse crops registered significant decline in area during period II (1985-86 to 2005-06) which started during eighties, due to increase in cultivated area of major cereal crops, oilseeds and other cash crops. Production increased significantly in almost all the pulse crops during overall study period except in case of Horse gram. Area and production of small Horse gram registered negative growth and highly significant during overall periods because the increased growth in per hectare yield is less than reduction in area.

\section{Decomposition of growth components}

The total change in the production of pulse crops was decomposed in to three effects i.e. area effect, yield effect and interaction effect (Table 5). The percentage contribution of area, yield, and their interaction is increasing or decreasing the production of pulses for each decades from 196566 to 2016-17 and overall period. The relative contribution of area, yield and their interaction in increasing the total production of pulse was 17.05 $\%, 48.33 \%$ and $34.66 \%$ respectively in the overall period of the study area. Table 3 revealed that, in period I except horse gram, the contribution of area and yield effect were positive for major crops and it was more responsible for the production of black gram, green gram, red gram and horse gram. In case of horsegram, the area effect was positive and yield effect was negative which influenced on horsegram production. The interaction effect was positive in black gram, moong, red gram and horse gram whereas in red gram it was negative.

Table 5: Decomposition Analysis for Major pulses in Tamil Nadu

\begin{tabular}{|c|c|c|c|c|}
\hline & $\begin{array}{l}\text { Period I } \\
(1965- \\
1985)\end{array}$ & $\begin{array}{l}\text { Period II } \\
(1986- \\
2005)\end{array}$ & $\begin{array}{l}\text { Period III } \\
(2006- \\
2016)\end{array}$ & $\begin{array}{l}\text { Overall } \\
\text { Period } \\
(1965-2016)\end{array}$ \\
\hline \multicolumn{5}{|c|}{ Black gram } \\
\hline Area Effect & 29.27 & 113.61 & -45.93 & -5.91 \\
\hline Yield Effect & 69.75 & -2.64 & 57.48 & 56.96 \\
\hline $\begin{array}{l}\text { Interaction } \\
\text { Effect }\end{array}$ & 0.87 & -10.71 & 88.28 & 48.88 \\
\hline \multicolumn{5}{|c|}{ Green gram } \\
\hline Area Effect & 64.22 & -145.35 & 474.95 & -168.28 \\
\hline Yield Effect & 25.06 & 139.46 & -17.93 & 62.40 \\
\hline $\begin{array}{l}\text { Interaction } \\
\text { Effect }\end{array}$ & 10.63 & 106.07 & -357.23 & 205.91 \\
\hline \multicolumn{5}{|c|}{ Red gram } \\
\hline Area Effect & 66.96 & 48.59 & -48.56 & 53.04 \\
\hline Yield Effect & 23.82 & 51.68 & 114.30 & -13.27 \\
\hline $\begin{array}{l}\text { Interaction } \\
\text { Effect }\end{array}$ & 9.17 & -0.21 & 34.32 & 60.20 \\
\hline \multicolumn{5}{|c|}{ Bengal gram } \\
\hline Area Effect & 18.96 & 27.84 & -2.83 & 9.68 \\
\hline Yield Effect & 102.14 & 146.53 & 119.32 & 78.46 \\
\hline $\begin{array}{l}\text { Interaction } \\
\text { Effect }\end{array}$ & -21.00 & -74.63 & -16.92 & 11.76 \\
\hline \multicolumn{5}{|c|}{ Horse gram } \\
\hline Area Effect & 214.45 & 45.62 & 144.20 & -25.99 \\
\hline Yield Effect & -149.94 & 74.08 & 94.44 & 222.51 \\
\hline $\begin{array}{l}\text { Interaction } \\
\text { Effect }\end{array}$ & 35.19 & -19.69 & -139.00 & -96.83 \\
\hline \multicolumn{5}{|c|}{ Total Pulses } \\
\hline Area Effect & 70.74 & 55.84 & -64.06 & 17.05 \\
\hline Yield Effect & 49.09 & 58.92 & 71.19 & 48.33 \\
\hline $\begin{array}{l}\text { Interaction } \\
\text { Effect }\end{array}$ & -19.75 & -14.76 & 92.87 & 34.66 \\
\hline
\end{tabular}


In total pulses, area and yield effects were positive and area effect was very high accounting for 70.74 per cent. In period II except green gram the interaction effect in positive, all other effects were negative for all crops. Total pulses production was highly influenced by area and yield effect. The negative yield effect was found to be the highest in Horse gram (-149.94) for period I and it was positive and highest in period II (74.08 per cent). Interaction effect was found to be positive and highest in Horse gram (35.19 per cent) for period I and it was lowest in Total pulses (-19.75).

In the case of period III, the Black gram, Green gram and Horse gram the area effect is negative. The negative area effect was found to be the higher in total pulses, Red gram and Black gram with 64.06, 48.56 and 45.93 per cent respectively, but in overall period the area effect was the highest in Red gram (53.04 per cent). In overall period all the effects were positive in Bengal gram and total pulses, whereas yield effect and interaction effect was positive in urad and green gram. Among the major crops, interaction effect was high in green gram production and yield effect was high in horse gram during overall study period.

In case of total pulses, yield effects were positively higher and they were responsible for total pulses production. The increase in production of Horse gram, Bengal gram, Green gram and Black gram was mostly due to yield effect $(222.51 \%, 78.46 \%$, $62.40 \%$ and $56.96 \%$ respectively), where the area effect contributed negatively in green gram, horse gram and black gram during the overall study period. The reduction in Red gram production was due to yield effect by $13.27 \%$, whereas in the Bengal gram the contribution of both area and productivity effect has been highly positive during the overall period. The interaction effect is positive for all pulse crop except Horse gram, while area effect was greater than the yield effect Red gram. In case of interaction effect green gram was found to be higher (205.91 per cent).The results of the decomposition analysis clearly indicates that change in yield was mainly responsible for changes in production for most of the pulse crops. It indicates that yield was a major driving force behind the temporal changes in production of most of the pulse crops in the state over the study period from 1965-66 to 2016-17.

\section{CONCLUSIONS AND POLICY IMPLICATION}

The present study highlighted the fact that the area, production, and yield showed increasing trends in pulses production in the state. The growth of area, production, and yield for pulses registered positive during overall period (1965-66 to 2016-17). In recent years, Tamil Nadu from an area of 7.85 lakh ha has achieved pulses production to the tune of 3.37 lakh tonnes, which is a record because pulses production was never beyond 1-2 lakh tonnes during the period 1965-1985. The major pulses growing districts are Villupuram, Thootukudi, Thiruvarur, Salem, Cuddalore and Nagapattinmam. Though there has been an upward and significant boom in terms of area, production and yield of overall pulses in Tamil Nadu, it became sluggish. There exist a gap between domestic demand and supply of pulses, which obligates us to import pulses.

The growth rate of total pulses area, production and productivity first decline and then increased in the overall period. The results of decomposition analysis revealed that yield and interaction effects were positively contributed to the production of pulses. The yield effect has a greater contribution in each decades separately except in sixties for Horse gram also in eighties for Black gram and Green gram and response to change in production in these periods is due to change in acreage. In sixties and the decade of 2006's the change in production was due the change in area. The interaction of area and yield is not much except the decades of 2006's. Overall the production is changed mainly due to yield affect.

It could be concluded that there has been a noteworthy performance in yield aspect of total pulses at the state. It was mainly due to the positive impact of government interventions like increasing government thrust in technological advancement, rapid and intensive extension services, and institutional support through different intervening programs like National Food Security Mission (NFSM) and A3P (Accelerated Pulses Production Programme). It may be counseled that government has to intrude and enhance the productivity of pulses to offset the gap between production and consumption of pulses with the aid of adopting proper strategies, technological breakthroughs have to be implicated 
on the way to enhance the yield of total pulses on par with total food grains, socio-economic impact assessment studies, supply chain management research, value chain evaluation research ought to be conducted from agricultural economics perspective, pulse farming and appropriate measures must be adopted to aid in coordinated researches and care have to be taken on value addition which enhances the revenue from pulses. To further increase the area under pulse cultivation and yield of pulses, research and policy support should be promoted which will help to increase per capita availability of pulses, reducing import dependence and to some extent it will stabilize the pulse prices.

Acknowledgments: I wish to record my profound sense of gratitude to Dr. K.R. Ashok, Director Tamil Nadu Agricultural University, Coimbatore-3, which has helped us during my Post Doctoral research work. The author also expresses her thanks to Indian Council of Social Science and Research for providing the financial support through ICSSR-PDF fellowship.

\section{REFERENCES}

Agricultural Statistics at a Glance. 2018. (various issues) Directorate of Economics and Statistics, Department of Agriculture and Cooperation, Ministry of Agriculture, Government of India, New Delhi.

Kannan, E. and Sundaram, S. "Analysis of Trends in India's Agricultural Growth" Working Paper 276, The Institute for Social and Economic Change, Bangalore.
Krishna Teja., Ramana Rao, S.V., Vishnu Sankar Rao, D. and Ravindra Reddy, B. 2017. Performance of oilseeds in India - a temporal analysis. Journal of Oilseeds Research, 34(1): 26-31.

Kumar, P. 1998. Food Demand and Supply Projections for India. Agricultural Economics Policy Paper, 98-01. Indian Agricultural Research Institute, New Delhi.

Latika Devi., Arivelarasan, T. and Jenny Kapngaihlian. 2017. Pulses Production in India: Trend and Decomposition Analysis. Economic Affairs, 62(3): 435-438.

Mundinamani, S.M., Basavaraja, H., Hosamani, S.B. and Mahajanashetti, B. 1998. An Economic analysis of growth rates in area, production and productivity of pulses in Karnataka. Karnataka Journal of Agricultural Sciences, 11(4): 961-964.

Narayan Sharma Rimala, Shiv Kumar, B., Singha, D.R., Chahalc, V.P. and Shalooa. 2015. Sources of Growth in Pulses Production in India. Agricultural Economics Research Review, 28(1): 91-102.

Praveen Kumar, N.S., Radha, Y., Subba Rao, D.V., Srinivasa Rao, V. and Gopikrishna, T 2018. Growth and Instability of Pulses Production in Andhra Pradesh, International Journal of Current Microbiology and Applied Sciences, 7(11): 2319-7706.

Sivasankari, B., Prema, P., Vasanthi, R. and Kalpana, M. 2019. Growth Performance of Pulses in Agricultural Prices in India (2018) (various issues) Directorate of Economics and Statistics, Department of Agriculture and Cooperation, Ministry of Agriculture, Government of India, New Delhi. 
